\title{
THE SERUM CREATININE CONCENTRATION OF NORMAL INDIVIDUALS ${ }^{2}$
}

\author{
BY EVALYN BARRETT AND T. ADDIS \\ (From the Department of Medicine, Stanford University School of Medicine, \\ San Francisco, California)
}

(Received for publication January 28, 1947)

In the preceding paper (1) it is shown that the blood urea concentration of subjects with intact renal function increases as their protein consumption increases. The conclusion is drawn that a relatively dependable inference from urea concentration to renal function requires a knowledge of the amount of protein a patient is taking and, in addition, a clinical situation that warrants us in excluding any sudden and pronounced increase in protein catabolism. In general, this second requirement is met when we deal with ambulatory patients, but at the first visit of every new patient the first requirement is lacking. Under the circumstances it would be well if we could measure some substance, other than urea, the concentration of which is uniquely determined by the functional capacity of the kidney. Unlike urea, this substance should have a rate of formation that is constant and that is unaffected by variation in food consumption. Creatinine may be such a substance. Its rate of flow into the blood stream is said to depend on the rate of transformation of creatine into creatinine (2). Its rate of excretion is independent of the amount of food protein that is eaten (3) and remains the same whether the muscles are active or at rest (4). We have therefore measured the variability of serum creatinine concentrations in individuals without proteinuria whose renal function was presumably unimpaired.

\section{METHOD}

\section{The conditions under which the observations were made}

The same subjects, the same diets, the same blood collections were used for the serum creatinine as for the blood urea concentration measurements (1). But within this identity of conditions there is concealed a difference that exists for creatinine but not for urea. At all levels of protein intake the food was devoid of preformed urea, but it was not free from preformed creatinine. When $\mathbf{0 . 5}$

1 This work was made possible by a grant from the Nutrition Foundation, Inc. gram of protein per $\mathrm{kgm}$. was taken there was no meat in the diet and so the food was creatinine-free. But on the 1.5 -gram and still more on the 2.5 -gram level there was an increasing consumption of meat, fish, and chicken. In cooking, some of the creatine of muscle is converted into creatinine, in an amount that varies, presumably, with time, temperature, and $\mathrm{pH}(5)$. Since the unaltered creatine of the meat does not appear in the urine as creatinine (6) and since an increase in protein consumption does not increase creatinine excretion (3) we may derive from the 24-hour rates of creatinine excretion of our subjects an indication as to the quantity of creatinine formed from creatine in cooking. These rates are given in Table $\mathrm{I}$.

\section{TABLE I}

Rate of creatinine excretion on a creatinine-free diet $(0.5 \mathrm{gram}$ protein per $\mathrm{kgm}$.) and on diets containing increasing amounts of cooked muscle tissue (1.5 and 2.5 grams protein per kgm. body weight)

Averages from groups of 10 subjects. Rates corrected for a body weight of $70 \mathrm{kgm}$.

\begin{tabular}{l|c|c|c}
\hline \hline & $\begin{array}{c}\text { 0.5 gram } \\
\text { per kgm. } \\
\text { creatinine }\end{array}$ & $\begin{array}{c}1.5 \text { grams } \\
\text { per kgm. } \\
\text { creatinine }\end{array}$ & $\begin{array}{c}2.5 \text { grams } \\
\text { per kgm. } \\
\text { creatinine }\end{array}$ \\
\hline & \multicolumn{3}{|c|}{ mgm. per 24 hours } \\
1940 observations & 1638 & 1766 & 1903 \\
Present observations & 1597 & 1743 & 1835 \\
\hline
\end{tabular}

If we take the average of both rates of creatinine excretion on the 0.5-gram diet as representing the endogenous creatinine, we note in Table I that this is increased by $137 \mathrm{mgm}$. on the 1.5 -gram and by $252 \mathrm{mgm}$. on the 2.5-gram protein diet. This increase we may reasonably attribute to the addition of exogenous creatinine formed in cooking. The point is worth mentioning because it may seem unfortunate that the conditions we chose for our observations include a variable that may prevent us from obtaining a true measure of the variability of serum creatinine concentrations in normal individuals. This would be true enough if the variability determination were our end, instead of being a means to our end of establishing a standard of normality for new patients, many of whom will certainly have taken varying amounts of cooked meats before we see them.

With the exception of the 9:45 p.m. collection, blood was drawn just before breakfast, lunch, and dinner, that is to say at as long a period as possible since the preceding meal. Preformed creatinine is rapidly.excreted 
and so the maximum increase in serum creatinine concentration may have occurred before we got our blood samples. We measured the serum creatinine concentration in 32 nurses about an hour to an hour and a half after a lunch that contained soup and meat. The average concentration was $0.98 \mathrm{mgm}$. per $100 \mathrm{ml}$. The average obtained in 16 nurses who had taken no soup or meat was $0.91 \mathrm{mgm}$. per $100 \mathrm{ml}$. From the standard errors of these means it was calculated that such a difference would arise from chance in about 5 of every 100 repetitions of the experiment. It is thus probable that a somewhat greater variability than the one we report in Table IV would have been found if we had made our observations at times other than those we selected.

We shall restrict ourselves to the present series of observations in determining the variability of serum creatinine concentrations. The group involved was distinguished from the 1940 group by the fact that one of the subjects was a woman. Though the point has never been established beyond reasonable doubt there is some indication that creatinine concentrations are a little lower in women than in men (7). In our series we have 257 observations on our 9 male subjects and 29 on $E$, our single woman subject. The mean for the men was $1.03 \mathrm{mgm}$. per $100 \mathrm{ml}$. and for subject E $0.95 \mathrm{mgm}$., but, from the standard errors of these means, it can be shown that the difference between them might readily arise by chance. We conclude that, for our particular purpose, we may include subject $E$ and use the total variability in judging the significance of observed concentrations in both male and female patients.

\section{The method of measurement}

The photoelectric cell has facilitated the measurement of the color of creatinine picrate but even so the order of precision is not high for normal serum creatinine concentrations. When tungstate filtrates are used, the color is so faint that the limit of capacity of the photoelectric cell in the Evelyn colorimeter is approached. In 1940 we used the standard Folin Wu method (8) except that we used an Evelyn instead of a Duboscq colorimeter. In the present series of observations 2 modifications were introduced. We took note of Peter's (9) statement that a 1.175 per cent solution of purified picric acid was preferable to the saturated solution usually used. At the suggestion of Phillips (10) all the reagents were brought to the same temperature before the reaction was started in a water bath that varied between $24.5^{\circ}$ and $26.2^{\circ} \mathrm{C}$., and this temperature was maintained until the color was read exactly 10 minutes after the reaction was initiated. When we compare those of the 1940 measurements with those of the present measurements which are strictly comparable it becomes clear that there is a difference between them which we can attribute only to these changes in technique.

The difference becomes apparent when we use the information given in Table IV. All of the examples of our present measurements fall within the range given by the average, $1.02 \mathrm{mgm}$., plus and minus twice the standard deviation of $0.118 \mathrm{mgm}$; but 5 of the 29 measurements
TABLE II

Comparison of serum creatinine concentrations measured in 1940 with concentrations measured in the present series in serum taken at the same time on the 5th day of each diet

\begin{tabular}{|c|c|c|c|c|c|c|c|}
\hline \multicolumn{4}{|c|}{1940 measurements } & \multicolumn{4}{|c|}{ Present measurements } \\
\hline $\begin{array}{c}\text { Sub- } \\
\text { ject }\end{array}$ & $\begin{array}{c}\mathbf{0 . 5} \\
\text { gram } \\
\text { protein } \\
\text { per kgm. }\end{array}$ & $\begin{array}{c}1.5 \\
\text { grams } \\
\text { protein } \\
\text { per kgm. }\end{array}$ & $\begin{array}{c}2.5 \\
\text { grams } \\
\text { protein } \\
\text { per kgm. }\end{array}$ & $\mid \begin{array}{l}\text { Sub- } \\
\text { ject }\end{array}$ & $\begin{array}{c}\mathbf{0 . 5} \\
\text { gram } \\
\text { protein } \\
\text { per kgm. }\end{array}$ & $\begin{array}{c}1.5 \\
\text { grams } \\
\text { protein } \\
\text { per kgm. }\end{array}$ & $\begin{array}{c}2.5 \\
\text { grams } \\
\text { protein } \\
\text { per kgm. }\end{array}$ \\
\hline $\begin{array}{r}1 \\
2 \\
3 \\
4 \\
5 \\
6 \\
7 \\
8 \\
9 \\
10\end{array}$ & $\begin{array}{l}\text { mg }^{m g} \\
0.99 \\
1.23 \\
1.12 \\
1.05 \\
1.20 \\
1.10 \\
1.07 \\
1.36 \\
1.30 \\
-\end{array}$ & $\begin{array}{c}m . \text { per } 100 \\
1.05 \\
1.28 \\
1.15 \\
1.06 \\
1.20 \\
1.15 \\
1.15 \\
1.32 \\
1.32 \\
1.12\end{array}$ & \begin{tabular}{|l|} 
ml. \\
0.99 \\
1.19 \\
1.13 \\
0.97 \\
1.07 \\
1.07 \\
1.05 \\
1.21 \\
1.24 \\
0.99
\end{tabular} & $\begin{array}{l}\mathbf{A} \\
\mathbf{B} \\
\mathbf{C} \\
\mathbf{D} \\
\mathbf{E} \\
\mathbf{F} \\
\mathbf{G} \\
\mathbf{H} \\
\mathbf{I} \\
\mathbf{J}\end{array}$ & $\begin{array}{l}\text { mgn } \\
1.05 \\
1.19 \\
0.99 \\
1.06 \\
0.89 \\
1.15 \\
0.92 \\
0.96 \\
1.01 \\
0.95\end{array}$ & $\begin{array}{l}n . \text { per } 100 \\
0.90 \\
1.22 \\
1.15 \\
1.13 \\
1.02 \\
1.09 \\
1.05 \\
1.00 \\
1.07 \\
0.93\end{array}$ & \begin{tabular}{|l|}
$m l$. \\
1.07 \\
1.09 \\
1.14 \\
1.15 \\
0.95 \\
1.05 \\
1.02 \\
0.99 \\
1.13 \\
1.01
\end{tabular} \\
\hline
\end{tabular}

made in 1940 exceed $1.26 \mathrm{mgm}$. , which is the upper limit of this range. For our purpose this is important because it is apparent that the standard we have set up is applicable only to measurements made with the particular technique we have described.

We have made these color determinations because we believe they measure creatinine. But if all we have been doing is to determine the variability of a color produced by various unknown chromogens there is no reason that we should suppose the resulting color to have any necessary reference to the kidney nor need there be any propriety in our proposal that we should take an increase in this color as a ground for questioning renal creatinineexcreting capacity. What direct evidence we have on this point, though of necessity it is neither statistically convincing nor wholly conclusive, is due to the development by Miller and Dubos (11) of 2 bacterial enzyme systems that specifically destroy creatinine. Having found an average serum or plasma "creatinine" concentration of $1.09 \mathrm{mgm}$. per $100 \mathrm{ml}$. in 15 normal individuals, they observed that these enzymes did away with a color equivalent to that produced by $0.99 \mathrm{mgm}$. of creatinine per 100 $\mathrm{ml}$. There is so little difference between 1.09 and 0.99 mgm. that we are left free to suppose that all of the color might have been due to creatinine 2 But, however that may be, our principal reason for confidence in a relation between the color and renal function is the indirect evidence provided by the, for the most part, unrecorded experience of a multitude of clinicians who have watched

2 It should be noted that in the serum of uremic patients Miller and Dubos found that not all of the color could be accounted for by creatinine (12). If this is confirmed we shall have to remember that at the higher levels of creatinine retention we cannot expect any direct relation between the degree of renal failure and the degree of the color we measure. 
the "creatinine" concentrations of their patients' sera gradually rise as the functional capacity of their kidneys slowly fell.

\section{The individual variability of the subjects}

In Table III we give the averages for each subject, derived usually from 12 determinations on the 0.5 -gram, 6 on the 1.5 -gram and 12 on the 2.5 -gram level of protein consumption. The averages for each subject for all 3 diets is given in the last column of this table, arranged in order of ascending magnitude. There is a gradual increase from $0.93 \mathrm{mgm}$. to $1.10 \mathrm{mgm}$. per $100 \mathrm{ml}$. and no one subject stands out as singular. Subject $D$, whose blood urea concentration was so high relative to the others (1), falls here well within the range of individual variation.

TABLE III

Individual average serum creatinine concentrations from observations made at all times of day on varying levels of protein consumption

\begin{tabular}{l|c|c|c|c}
\hline \hline & \multicolumn{4}{|c}{ Food protein consumption } \\
\cline { 2 - 5 } $\begin{array}{c}\text { Sub- } \\
\text { ject }\end{array}$ & $\begin{array}{c}\text { 0.5 gram } \\
\text { protein } \\
\text { per kgm. }\end{array}$ & $\begin{array}{c}1.5 \text { grams } \\
\text { protein } \\
\text { per kgm. }\end{array}$ & $\begin{array}{c}2.5 \text { grams } \\
\text { protein } \\
\text { per kgm. }\end{array}$ & $\begin{array}{c}\text { Individual } \\
\text { averages for } \\
\text { the 3 diets }\end{array}$ \\
\hline \multicolumn{4}{|c}{} \\
G & \multicolumn{4}{|c}{ mgm. per 100 ml. } \\
H & 0.92 & 0.92 & 0.95 & 0.93 \\
E & 0.96 & 0.88 & 0.94 & 0.93 \\
J & 0.91 & 0.96 & 0.99 & 0.95 \\
A & 1.05 & 0.98 & 0.98 & 0.98 \\
B & 1.06 & 1.03 & 1.01 & 1.03 \\
C & 1.08 & 1.01 & 1.05 & 1.05 \\
D & 1.07 & 1.11 & 1.09 & 1.09 \\
F & 1.07 & 1.14 & 1.08 & 1.09 \\
I & 1.13 & 1.04 & 1.08 & 1.09 \\
\hline
\end{tabular}

\section{RESULTS}

The measurements given in Table IV show quite decisively that variation in protein consumption has no effect in the serum creatinine concentration. Our standard can therefore rest on all the $286 \mathrm{de}-$ terminations. The average is $1.02 \mathrm{mgm}$. per 100 $\mathrm{ml}$. and the standard deviation is $0.118 \mathrm{mgm}$. If we add twice the standard deviation to the average we have an upper range from 1.02 to $1.26 \mathrm{mgm}$. within which all but about 2 per cent of determinations will lie unless some other factor intervenes that did not exist in the subjects or in the conditions that we observed. The nature of the factor remains, of course, a question for clinical judgment.
TABLE IV

Averages and variabilities of serum creatinine concentrations on varying and on all levels of protein consumption

\begin{tabular}{|c|c|c|c|c|}
\hline & \multicolumn{4}{|c|}{ Food protein consumption } \\
\hline & $\begin{array}{c}\mathbf{0 . 5} \\
\text { gram } \\
\text { protein } \\
\text { per } \\
\mathbf{k g m} .\end{array}$ & $\begin{array}{c}1.5 \\
\text { grams } \\
\text { protein } \\
\text { per } \\
\mathbf{k g m} .\end{array}$ & $\begin{array}{c}2.5 \\
\text { grams } \\
\text { protein } \\
\text { per } \\
\mathbf{k g m} .\end{array}$ & $\begin{array}{c}\text { All } \\
\text { observa- } \\
\text { tions } \\
\text { on all } \\
3 \text { diets }\end{array}$ \\
\hline $\begin{array}{l}\text { Average serum creati- } \\
\text { nine concentration } \\
\text { Number of observations } \\
\text { Standard deviation } \\
\text { Standard error }\end{array}$ & $\begin{array}{c}1.020 \\
110 \\
0.126 \\
0.012\end{array}$ & $\mid \begin{array}{c}1.020 \\
60 \\
0.123 \\
0.016\end{array}$ & $\mid \begin{array}{c}100 \mathrm{ml} \\
1.030 \\
116 \\
0.106 \\
0.010\end{array}$ & $\begin{array}{r}1.020 \\
286 \\
0.118 \\
0.007\end{array}$ \\
\hline Coefficient of variation & \multicolumn{4}{|c|}{ per cent } \\
\hline
\end{tabular}

\section{DISCUSSION}

Figure 1 contrasts the behavior of creatinine and urea as the protein consumption of normal individuals is increased.

With creatinine-concentration measurements we are delivered from the effect of a variable that obscures the significance of the urea or non-protein nitrogen determinations. We thus have a measure that we can use with assurance in the numerous clinical situations in which we have no precise information as to the rate of urea formation.

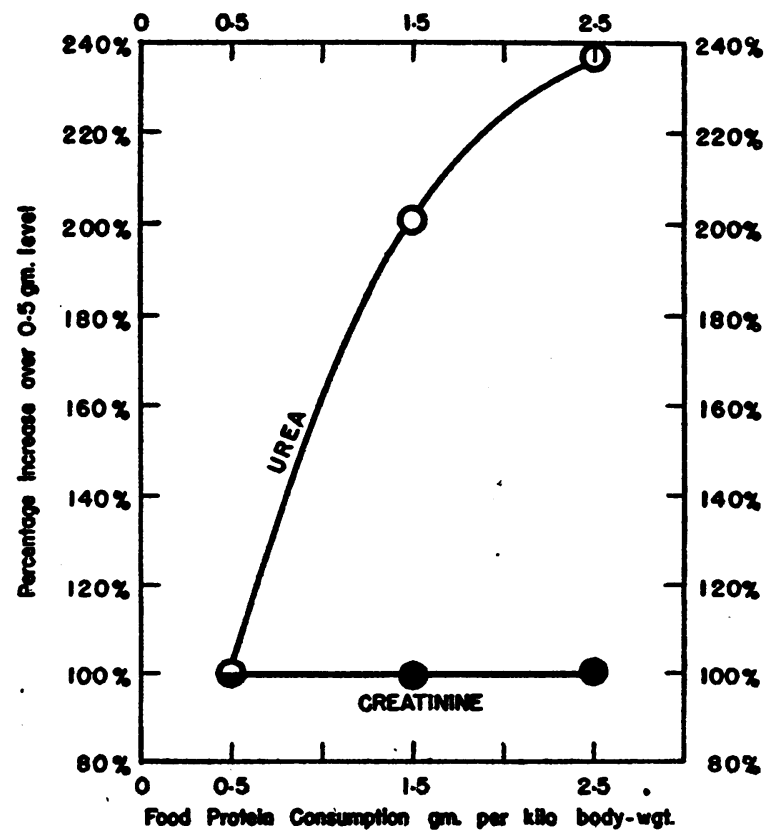

Fig. 1. For Serum Creatinine Concentration or NORMaL InDIVIDUALS 


\section{CONCLUSIONS}

1. The average of 286 determinations of creatinine concentration in the serum of 10 medical students was $1.02 \mathrm{mgm}$. per $100 \mathrm{ml}$. The range of variation that included 95 per cent of the measurements extended from $0.78 \mathrm{mgm}$. to $1.26 \mathrm{mgm}$. per $100 \mathrm{ml}$.

2. Variation in protein consumption from 0.5 to 2.5 grams protein per $\mathrm{kgm}$. body weight had no effect on the serum creatinine concentration.

We are indebted to Dr. Horace Gray for advice and help in the statistical treatment of the data.

\section{BIBLIOGRAPHY}

1. Addis, T., Barrett, E., Poo, L. J., and Yuen, D. W., Relation between serum urea concentration and protein consumption of normal individuals. J. Clin. Invest., 1947, 26, 869.

2. Hunter, A., Creatine and Creatinine, Monographs on Biochemistry. Longmans, Green and Co., London, 1928, p. 147.
3. Folin, O., Laws governing the chemical composition of the urine. Am. J. Physiol., 1905, 13, 66.

4. van Hoogenhuyze, C. J. C., and Verploegh, H., Boebachtungen über die Kreatininausscheidung beim Menschen. Zeit. f. physiol. Chem., 1905, 46, 415.

5. Zickelbein, U., Uber die Kreatin-Kreatininausscheidung mit dem Harn bei fleischfreier und fleischhaltiger Nahrung. Zeit. f. d. ges. Exp. Med., 1933, 87, 112.

6. Afklercker, K. O., Zur Frage der Kreatin-und Kreatininausscheidung beim Menschen. Beitr. chem. Physiol. und Path., 1906, 8, 59.

7. Hunter, A., and Campbell, W. R., The amount and the distribution of creatinine and creatine in normal human blood. J. Biol. Chem., 1918, 33, 169.

8. Folin, O., and Wu, H., A system of blood analysis. J. Biol. Chem., 1919, 38, 81.

9. Peters, J. H., The determination of creatinine and creatine in blood and urine with the photoelectric colorimeter. J. Biol. Chem., 1942, 146, 179.

10. Phillips, R. A., Personal communication.

11. Miller, B. F., and Dubos, R., Studies on the presence of creatinine in human blood. J. Biol. Chem., 1937, $121,447$.

12. Miller, B. F., and Dubos, R., Determination by a specific enzymatic method of the creatinine content of the blood and urine from normal and nephritic individuals. J. Biol. Chem., 1937, 121, 457. 